\author{
Merima Omeragić \\ Univerzitet u Sarajevu, Centar za interdisciplinarne studije \\ merima.omeragic@unsa.ba \\ Merima Omeragić \\ University of Sarajevo, Center for Interdisciplinary Studies \\ merima.omeragic@unsa.ba
}

\title{
OD ISTORIJSKE POGIBIJE HIFZI-BEGA ĐUMIŠIĆA DO BALADNE REPREZENTACIJE ZBILJE
}

\section{FROM HISTORICAL DEATH OF HIFSI-BEY ĐUMIŠIĆ TO THE BALLADESQUE REPRESENTATION OF REALITY}

U radu se analiziraju povijesni i književnoumjetnički prosedei koji za osnovu imaju prelaz istorijske ličnosti Hifzi-bega Đumišića u književni lik. Razmatanje odnosa povijesne zbilje i usmenoknjiževne zbilje ili puta transformacije/poetizacije je pitanje zapamćivanja junaka i motiva u tradiciji (usmeni model) putem modifikacije, diskontinuiteta i folklorizacije. Motiv izdaje i stradanja je bio presudan za baladu, a junačka snaga i plemenit čin za oblikovanje epske pjesme. Motiv pogibije literarizacijom je prošao kroz dva nivoa: identifikacije i prepoznavanja folklornih predstava u istorijskom narativu /zapamćivanje i ulazak u tradiciju/ te dodatnog domaštavanja (folklorne predstave naroda). Akcenat u istoriji je na motivu uzroka, a u pjesmama na motivima balade. Poređenje istorijskih i poetskih podataka u usmeno-književnom pamćenju potvrdilo je načine preoblikovanja, transmisije istorijskog u usmeno-pjesničko. zbilja.

Ključne riječi: istorijski narativ, poetizacija, varijante, folklorne funkcije, odnosi

This work analyses the historical and artistic literary methods employed in the transition from the historical person Hifzi-bey Đumišić to a literary character. The unravelling of the relationship between the historical reality and the oral literary reality or the path of transformation/poetization is a matter of memorization of the hero and the motifs in the Tradition (oral model) through modification, discontinuity and folklorization. The motif of betrayal and perishing was decisive for the ballad, while heroic strength and the magnanimity of his deeds shaped the epic. Literarization treats the motif of perishing on two levels: identification and recognition of the folkloric representation in the historical narrative/memorization, and its introduction in the tradition and additional imagining (of the folkloric representation of people). The emphasis in history is on the theme of cause, while in songs it is on the themes of the ballad. The comparison of historical and poetic data in the oral literary memory validates the modes of reshaping and transmission of the historical into the oral poetic. relations.

Keywords: historical narrative, poetization, variations, folkloric function, reality 


\section{Istorijski Hifzi-beg Đumišić kao baladni junak: podobnost priče za usmenoknjiževnu obradu}

Istorija danas u bespućima pada vlastitog narativa u epistemološkom smislu dobija na značaju u dimenziji opasnih zabluda linearnih tokova pripovijedanja i pričanja istina o pobjednicima (pravednicima) i gubitnicima (nasilnicima). U smislu političke teorije i kritike istorija je najtačnija priča o preraspodjeli i zloupotrebi Moći i potencijalima za buduću dobrobit isključivo pobjednika.

Važne aspekte konteksta istorijskog narativa čine geopolitička preslojavanja (naslage) što se u uzusima (i postkolonijalnih) čitanja ogleda i kroz deridijansku ideju responsivnosti spram Drugih/raznovrsnih, to jeste kroz odgovornost kao prostor intersubjektivnosti. Prostori Balkana veoma su specifični zbog bremena diskursa, kako balkanizamskih (i/ili orijentalnih) zapadnjačkih predstava ${ }^{1}$ tako i unutrašnjih re/prezentacija. Zajednička tačka ovim diskursima je marginaliziranje i sataniziranje neprijateljskog Drugog te afirmacija vlastite superiornosti. Negativno determinirana razgraničenja su pokazala da hijerarhiziranje jeste prozvod svijesti, a ne stvarnih i nepomirljivih razlika. Za razliku od Zapada koji u balkanizamskim predodžbama vidi sporni fenomen „raskrsnice“ kojim opravdava generiranje dominacije kako bi osigurao prevlast nad ovim prostorima (i orijentalistički nepoželjnih kultura), balkanski stereotipi iznutra koje njeguju različiti narodi Balkana jedni o drugima i nama samima imaju korijen u sukobu divljeg islama hrišćanskoj Evropi. U to ime prezrenu Drugost neophodno je pokoriti što znači ,legalizovati diskursivnu kolonijalnu praksu potrage za prezrenim krivcem, čime se obezbjeđuje dugotrajniji učinak samodefiniranja, trajna gradnja kao i opstanak integriteta" (Omeragić 2012: 448). Dekontaminiranje 'balkanskog tla' od produkcije predrasuda i (auto)stereotipa koji su osnovica i materijal za re/produciranje ideologija kojima se proizvode diskursi moći postavlja se kao vitalan zadatak u raspetljavanju čvorova naše kulture.

Nesreća pripadnosti Bosne Balkanu postaje najizazovniji problem razmatranja istorije i kolonijalizma. Najdominantnija teza o nemoćnoj potčinjenosti ovog prostora je priča o osvajanjima Osmanskog Carstva, ${ }^{2}$ položaju stanovništva u Bosni, kao i položaju same imperije na evropskom tlu. Viševjekovna prevlast nad domicilnim stanovništvom, neizostavan harač, janjičar-

1 Usp. Todorova Marija. Imaginarni Balkan. Beograd: Biblioteka XX vek, 2006. Said Edvard. Orijentalizam. Beograd: Biblioteka XX vek, 2008.

2 Srednjovjekovna kraljevska Bosna je pala pod otomansku vlast (sultan Mehmed II) 1463. godine. U prvi mah je otpočeo proces islamizacije stanovništva, prvenstveno bosanskog plemstva, a naporedo s tim dinamičnim procesom, uspostavljenja je i nova vlast u kojoj je Bosna proglašenja sandžakom, kasnije i ejaletom. Poreska i carinska politika koju je provodilo Carstvo u Bosni brzo se pokazala kao jedna od temeljnih razloga prelaska domaćeg stanovništva na Islam jer su porezi koji su muslimani plaćali državi bili mnogostruko manji od poreza kršćanske raje (Usp. Tanović Bakir. Historija Bosne u okviru Osmanskog carstva. Sarajevo: Svjetlost, 2010.) 
stvo, potom odnos velikih evropskih sila (ruska i austro-ugarska sa svojim interesima i izazivanjem takozvane Istočne krize) spram Carstva u zadnjim decenijama 19. vijeka dovele su do podjela i konačne predaje Osmanlija i „povlačenja“ sa evropskog tla. U igrama oko prevlasti i moći zainteresiranih strana izmanipulirano stanovništvo u Bosni moralo je podnijeti teret namontiranog rata sa početkom označenim u istoriji kao „Bosanski ustanak 1875 / 61878“ i anektiranje Bosne od strane Austro-Ugarske. Broj žrtava seljačkog ustanka samo u Bosni i Hercegovini prelazi cifru od 150.000 ljudi. $^{3}$

Kada je u pitanju problem pluralnosti istine istorijskog diskursa, potrebno je naglasiti dvije specifične pozicije tumača bosanskog ili seljačkog ustanka. Najreprezentativniji istoričari prve grupe su Vaso Cubrilović i Milorad Ekmečić koji se slažu u činjenici da je Hercegovački ustanak (1875) proizvod nezadovoljstva hrišćanskih kmetova/seljaka koji su bili u nezavidnom položaju stupanjem na snagu deseteračkog poreza kao i zbog oholog odnosa muslimanskih begova i aga spram ugroženog stanovništva. Radi alarmantnog stanja u klasi kmetova vlasti su počele da razmještaju vojne jedinice po mjestima, opremaju muslimanske zajednice te šalju odrede koji su hapsili ugledne starješine i seljake te ih vezane tjerali iz sela. Prilikom prolaska kroz sela zaptije su ,ucenjivali pojedine seljake i od njih naplaćivali globe“ što je rezultiralo snažnim otporom seljaka koji su ,u pokušaju da odbrane ljude od hapšenja poubijali zaptije“" (Ekmečić 1973: 79).

Savremeniji istoričari, nedvojbeno muslimanske orijentacije poput $\mathrm{Mu}-$ stafe i Envera Imamovića, Husnije Kamberovića i Bakira Tanovića sagledavaju dimenzije ustanka koje se tiču upliva vanjskih politika (podrške ruske imperije) $i$ tendencija da se preuzme vlast nad Bosnom. Jednoznačno signiran povod ne bi imao oslonac da istorijska priča nema dodatne dvije dimenzije: otpor muslimanskih begova prema Porti i težnja za autonomijom. Autonomija bi obezbijedila dominaciju i isključivu moć. Druga dimenzija je „rušenje postojećeg agrarnog sistema i stvaranje slobodnog seljačkog posjeda" (Imamović 1998: 208) što je podvlačenje socijalne dimenzije ustanka pod buđenje svijesti kod hrišćanskog stanovništva za što su prema navodima istoričara odgovorne vjerske vođe $i$ grupe, a što je $u$ historiografiji označeno kao „motiviranje nacionalnom mržnjom i vjerskom netolerancijom“ (Tanović 2010: 520). Poređenje ova dva istorijska pristupa značajno je za što bolje razumijevanje društvene situacije ne samo u naučnom smislu, već i u smjeru oblikovanja narodne svijesti te prenošenja određenih motiva iz tradicije u vrijeme nastanka balade i epike. U uzajamnom djelovanju istorijskih događaja i naslijeđenih motiva tradicije odvija se ono što Novak Kilibarda slijedeći ideje Borisa N. Putilova na osnovu istorijsko-tipološke metodologije i teorije navodi: „one metodologije kojom se dokazuje da junački ep, kao jedna od univerzalnih formi folklornoga stvaralaštva, ne počinje s prikazivanjem i opisivanjem stvarnih istorijskih

3 Broju treba pribrojati još i žrtve u drugim zemljama na koje se ustanak prenio: sa Hercegovine na sve dijelove Bosne, Sandžaka, Makedonije i Bugarske. 
ličnosti, nego izvorište junačkog epa čine najstarije naslage etničke istorije, shvaćene i formirane jezikom mita“ (Kilibarda 2012: 157-158). Centralne figure istorijskih narativa su figure nacionalnog heroja proizvedene koreliranjem heroiziranja žrtve, narodnog zapamćivanja, akcentiranja i domaštavanja dijelova priče. Opetovanje određenih ličnosti i / ili likova odvija se kroz ponovljivost $\mathrm{i}$ upotrebljivost kao i odnose istorijskog i književnog narativa uopšte.

Zasigurno najveća muslimanska istorijska i junačka ličnost Bosanskog ustanka jeste Hifzi-beg Đuišić „major tuzlanske vojne posade“ (Kamberović 2005: 315). Osebujni junak je potomak poznate begovske porodice Đumišić koja se isticala posebno po bogatim kotarskim posjedima širom Bosne i Hercegovine. ${ }^{4}$ Smatra se da je Hifzi-beg kao najstariji sin plemićke prodice rođen oko 1840. godine. Istorijski detaljni podaci o životu bega Đumišića nisu poznati, osim njegove svadbe (velike i po značaju onakve kakvu Banja Luka nije zapamtila), vojništva i pogibije. Pažnja istorije, ali podjednako i književnosti usmjerena je na ključni trenutak njegova života — pogibiju. Najvjerodostojniji zapis o tačnim činjenicama vezanim za pogibiju Hifzi-bega sačuvan je u sarajevskom Zemaljskom muzeju kao službeni akt turske arhive. Dio akata odštampan je u Novom Beharu 1927. godine u članku „O junačkoj smrti Hifzibega Đumišića“ koji potpisuje Riza Muderizović. ${ }^{5}$ Sve rekonstrukcije smrti Hifzi-bega Đumišića su potekle iz ovih ili rjeđe Hadžijahićevih zapisa (uz odstupanja) ${ }^{6}$ pri čemu se svi autori bilo istoričari ili književni istoriografi referiraju upravo na Muderizovićev tekst.

Posebno zanimljiv koncept ili nimalo začuđavajuća činjenica kad je u pitanju pogibija bega Đumišića u koju je nesmunjivo upleten i Salih Zekipaša jeste potreba nekih istoričara da njegovo ušešće cenzuriraju ili opravdaju ${ }^{7}$ uz naglašavanje uloga koju su imali Atanas Petrović i Jovo Okanović. Uprkos različitim tumačenjima, neosporna je činjenica da je Đumišićeva smrt rezultat izvršavanja vojne naredbe koju je naložio Zeki-paša Hifzi-begu kao svom podređenom u sistemu vojnog hijerarhiranja. Važan podatak o Hifzi-begu predstavlja i odlikovanje koje je primio vrlo brzo nakon dobrovoljne prijave u vojsku (na poziv Dževdet-paše 1864. godine), kao i njegov munjeviti napre-

${ }^{4}$ Hifzi-begov otac Mehmed Nazif-aga je važio za „,najznamenitijeg spahiju u banjalučkom katunu“ (ovaj navod Husnija Kamberović preuzima od Ivana Kukuljevića) a ujedno je bilo poznato da je Hifzi-begov otac bio „strašan zulumćar“(Hadžijahić 1934: 174-175) koji je završio u progonstvu sa drugim znamenitim ličnostima koje su vršile nasilje.

5 Važnost ovog članka naglašava ne samo autorstvo koliko i signirana fusnota koja slijedi iza naslova rada, a kojom se potvrđuje da su činjenice preuzete iz Službenih akata turske arhive koje se nalaze u Zemaljskom muzeju u Sarajevu.

6 Tekst Muhameda Hadžijahića je objavljen u Novom Beharu 1934. godine, pod naslovom „Hifzi-beg Đumišici“".

7 Nastranu očigledna vjerska netrpeljivost istorijskog tumača, sam Riza Muderizović u svom tekstu naivno i neuvjerljivo opravdava učešće Salih Zeki-paše, tvrdeći da je on bio 'zaveden' od strane Petrovića i Okanovića. S druge strane, Midhat Spahić u svojim tvrdnjama ide i dalje opravdavajući postupak Zeki-paše, ali njegove zaključke je nužno dovesti u pitanje s obzirom na to da ne navodi citate koje preuzima od Muderizovića, već ih predočava kao svoje (sic!). 
dak u „čin majora“ (Hadžijahić 1934: 174-175) te junaštvo koje je bilo čuveno čak i u Porti što je izazivalo ljubomoru i zavist kod sujetnih nadređenih.

Unatoč činjenici da se brašno moglo otkupiti od begova te da je dokazano u „Bijeljini u magazinu bilo za vojsku hrane još za 5-6 dana i da sa strategijskog pogleda nije bilo umjesno slati kola i vojnu pratnju u pravcu neprijateljskog povlačenja“" (Muderizović 1927: 8-9), naredba Salih-paše je bila izvršena. Prema navodima Rize Muderizovića i svjedočenju Jove Okanovića na sudu ${ }^{8}$ vojni nabavljač Atanas Petrović je dojavio Salih-paši da je zaprimio brzojav od banke u kojem stoji da treba da preuzmu 150 vreća brašna u Rači potrebnog „jer brašna nema više u magazinu u Bijeljini za ishranu vojske“ (Muderizović 1927: 8-9). Salih-paša izdaje naredbu civilnim vlastima da se potrebna kola spreme za transport. ${ }^{9} \mathrm{Uz}$ Petrovićevu dezinformaciju s terminom isporuke i navalu vojske, umjesto da „odustane sasma sa dovozom brašna iz S. Rače, koje se inače moglo pribaviti iz begovskih hambarova, gdje je ležalo na hiljade tovara ili eventualno iz Brčkog pa i iz Zvornika“" (Muderizović 1927: 8-9), Salih Zeki-paša šalje vojni bataljun pod komandom Hifzi-bega Đumišića, koji bi obezbijedio sigurnost dovoženja brašna. Okanović saznavši da nema brašna u Rači nakon ikindije dolazi da obavijesti bega Đumišića koji izdaje naredbu za povratak. Negirajući upozorenja carinika i „svojih vojnika“ (Hadžijahić 1934: 174-175), Đumišić, oslanjajući se na svoje junaštvo, kreće natrag istim putem u Bijeljinu. Usput nailazi na tri vojne zasjede. Pobijedivši u prve dvije Hifzi-beg dolazi do treće busije i gine u noćnoj tmini, napuštajući vojsku sa kolima i konjima.

Sagledavajući istorijske okolnosti pod kojima se odvilo zapamćivanje usmene predaje o Đumišićevom stradanju, preoblikovanje u baladne i epske pjesme, može se sa sigurnošću potvrditi dosadašnji stav istraživanja književne istorije da su motiv izdaje i stradanja bili ključ za baladu, a junačka snaga i plemeniti čin za oblikovanje epske pjesme. I kad ne bi cjepidlačili oko utvrđivanja identiteta prvog pjevača ${ }^{10}$, nerazjašnjene okolnosti pod kojima je poginuo radi plemenita cilja (kao žrtva izdaje) utjecale su na nepoznate pjevače da preoblikuju ovaj motiv u umjetnost. Ovom književnoumjetničkom usmenom formom ličnost je reprezentirana uz dejstvo tragične hamartie i hybrisa — kako bi Hifzi-beg Đumišić postao junački epski i /ili baladni lik. Stoga je donekle, u smislu obje zbilje, logična Maglajlićeva tvrdnja da je ,zavjera mogla biti izmišljena da bi opravdala pogibiju jednog glasovitog junaka“ (Maglajlić

8 Jovo Okanović je preslušavan od strane vlasti zbog optužbe vlasnika kola da je načinio štetu nad njihovom imovinom. Njegov zadatak je bio da primi brašno u S. Rači.

9 Salih Zeki-paši, nažalost, nije suđeno pred vojnim ratnim sudom za pogrešne strategijske poteze koji su izazvali smrt dosta ljudi i njegovih podređenih, što naglašavaju i drže obaveznim najraniji istoričari.

10 Prema usmenoj predaji tuzlanskog kraja, Đumišić je imao u svojoj „pratnji pjevača koji je kao najposredniji očevidac zbivanja mogao biti i prvi pjesnik balade o njegovoj pogibiji" (Maglajlić 1995: 33). Jedna varijanta direktno pominje Hamzu koji treba za oproštaj sa Himzi-begom da svira „Asker juriš‘“ (Usp. Kuba 1984: 98-99.). 
1995: 32). Razmatranje odnosa istorijske i usmenoknjiževne zbilje, transformiranja i poetizacije pitanje je zapamćivanja i ulaska junaka i motiva u tradiciju. Naime, istorijske ličnosti i ovako zapisan događaj pogodovao je i poklopio se sa zahtjevima i zakonitostima epskog ustrojstva i stvaranja „tipova epskih junaka i njihovih protivnika“"(Kilibarda 2012: 158).

Povijesni događaji se mogu identificirati u pjesmama jer su kao sjećanje na događaj, modifikovani i pojednostavljeni ušli u tradiciju kao usmeni model, na osnovu sljedećih etapa: rat, Hifzi-begovo hrabro izvršavanje zadatka, upletenost Zeki-paše, Petrovića i Okanovića te datum pogibije 23. juna 1876. godine. Pomenuta istorijska izdaja — čak i kao loš strategijski potez je jednoznačna i nedovoljna u kontekstu usmenoknjiževnog pamćenja. Ulazak bega Đumišića u sjećanje i usmenu tradiciju, prije svega, dugujemo predimenzioniranju i tumačenju njegove ličnosti kao herojske. ${ }^{11}$ Usmena poezija posimboličena je težinom izbora i zadatka kojeg je Hifzi-beg Đumišić kao junak trebao izvršiti. Nizu njegovih karakteristika može se dodati: borba za samostalnost Bosne, potomstvo slavne i ugledne porodice, njegova slavna vojna karijera kao i „njegova probosanska orijentacija“ (Buturović 2010: 90) što su sve podsticaji za pamćenje i ulazak u proces poetizacije stradanja istorijskog bega Đumišića. Terminom probosanski autorka cilja na istorijske tendencije osamostaljenja Bosne i svojevrsnog otcjepljenja od uticaja koliko turske imperije i nadolazećih austrougarskih kolonizatora, vanjskih političkih uticaja, toliko i susjednih naroda i zemalja. S tim prelomnim trenutkom u bosanskoj istoriji koji se reflektira i na samu usmenu književnost i tradiciju naroda označava polje aktualne borbe oko samostalnosti i nezavisnosti. Sinteza istorijskog, epa i na kraju baladnog što rezultira fenomenom istorijske balade predstavlja prema riječima Borisa N. Putilova ,umjetnički spomenik nacionalne narodne umjetnosti; u njima su zarobljene stranice narodne istorije sa svojim tragedijama i prastare borbe; izraz su svijesti naroda koji se nisu pomirili sa stranim jarmom i koji su branili svoje dostojanstvo i slobodu“ (Путилов 1965: 175). Iako su navedene tvrdnje iznesene povodom drugih slavenskih tradicijskih krugova, njegov argument proizašao iz dubinskog shvatanja motiva naroda, univerzalističkog tipa svakako je primjenjiv i na težnje za postizanjem slobode stanovništva Bosne (pa i Hercegovine), koliko hrišćana, toliko i muslimana.

\section{Poetizacija pogibije Hifzi-bega Đumišića - prilog korpusu istorijske balade}

Topos međuticaja i relativnosti od identificiranja istorijske ličnosti do njenog ulaska u usmenu književnost je područje reafirmacije „uzroka nastanka pjesama“" (Bejtić 1953: 631) ali i ozbiljna potvrda da su ličnosti opjevane u lirskim pjesmama dio „istinske prošlosti“. Zamećene modifikacije koje nastaju

11 Junaštvo je uzdignuto do mitskih visina - metafora prevoženja brašna je čin borbe za opstanak i produženje života. 
transformacijskim dejstvima ${ }^{12}$, tačke gledišta na određeni događaj, preslojavanjima narodnih tumačenja istorijskih događaja i tereta sudbine povijesnog pojedinca u različitim varijantama su od vrijednosti (pogotovo uzrok), preuzimanje teme bliske narodnom duhu, epohalno-društvenom sistemu vrijednosti, svjedočanstvo svakodnevici, ali i onoj vrsti tradicije koja se ostavlja u naslijeđe optimizmu i pravdi za potomke.

Pjesme poput braće Morića i na smrt osuđenog Ibrahim-bega su česte u muslimanskoj sredini kad je riječ o baladi istorijskog tipa. Istorijska balada i njeni ,zapleti su rezultat odabira i umjetničke obrade fenomena stvarnosti (Путилов 1965: 31). U korpusu bošnjačke istorijske balade najvažniji lik koji funkcionira kao prototip povijesnog junaka ${ }^{13}$ (premostivši put od ličnosti do lika) jeste Hifzi-beg Đumišić. Upravo u tom međašenju poetizacije istorijskog događaja, a koje se odnose na njihovu narativizaciju u lirsko-epskoj formi, leži karakter junaka i neizbježnost njegove sudbine. U takvom kontekstu povezivanje mjesta/prostora sa junakom, brzina razvoja događaja, intenzitet, pojedinačnost iskustva, čovjekov život $u$ trenutku napetosti, sukob sa društvenim okruženjem i normama, politička izdaja dodatni su elementi determiniranja istorijske balade. Rezultati pjesama su tragično stradanje junaka što se redefirnira od epske ka baladnoj zbilji akcentiranjem uzvišene smrti. Dva pomenuta motiva, motiv izdaje i motiv herojske pogibije su međusobno determinirani. Osim što određuju jedan drugog, motiv izdaje koji je tipičan za epsku poeziju stoji naspram baladnog stradanja pravednog junaka i funkcionira kao presudan „za oblikovanje ove balade“ (Maglajlić 1998: 450). Na razini žanra, motiv izdaje dodatni je osnažujući, stilski efekt kojim se stiliziraju elementi istorije u smjeru kompletiranja fenomena istorijske balade. Motiv izdaje unapređuje baladnu radnju već od samih inicijalnih stihova, uvodeći slušaoce $\mathrm{u}$ istorijski motiv (zazivanjem istorijskih ličnosti Salih-paše i srpskog knjaza) i predodređujući dvije dimenzije: emotivni angažman slušaoca pri zauzimanju strane uz nedužnog junaka (dobročinitelja naše zajednice) i u skladu s tim društvenog repozicioniranja i s druge strane najava neizbježnog, uzvišenog stradanja bez ikakve stvarne krivice junaka bega. Tranzicija motiva izdaje od epike ka istorijskoj baladi specifičan je utoliko što prenosi emotivnu snagu, ali i koji se nameće kao „konstitutivan motiv za ovu baladu“ (Maglajlić 1998: 452). Izdaja koja funkcionira kao uzrok stradanja Hifzi-bega Đumišića producira specifičan muslimanskom tradicijom obogaćen motiv stradanja junaka i posebno motiva opraštanja junaka sa zemaljskim svijetom. Izdaja kao uvodni i motiv opraštanja junaka kao završni motiv osim što zaokružuju pripovjednu razinu balade, oni sumiraju plemenitost, dobrotu i hrabrost bega Đumišića veću od izbora na život.

12 Potrebno je razjasniti načine na koji narod — usmeni pjevači/ice pamte prošlost.

13 Povijest se prelama kroz pojedinca suočenog s njenim dejstvima. Na horizontu istorijskih događanja nema šansu da pruži bilo otpor ili načini izbor koji neće biti u skladu sa nasiljem neumitnosti razvoja događaja koji slijede prema već pomenutom obrascu na relaciji pobjednika - gubitnika. 
U proputovanju Bosnom, Ludvik Kuba, 17 godina nakon pogibije Đumišića, prvi bilježi dvije varijante ove pjesme (Stolac i Višegrad) objavljene početkom 20. vijeka. ${ }^{14}$ Pored ova dva napjeva, prvu cjelovitu varijantu pjesme o begu Đumišiću donosi Mehmed-beg Kapetanović Ljubušak. ${ }^{15}$ Treću varijantu bilježi Jovan P. Munitić dok se najpoznatija epska varijanta nalazi u zapisima Koste Hoermanna. Do danas je zabilježeno oko 20-tak baladnih varijanti pjesama o pogibiji Hifzi-bega Đumišića. U odnosu na ishod primjetno je da su popularnije i poznatije verzije baladnog opjevavanja pogibije. Pjesme baladnog osjećaja svijeta u svim razlikama oblikovanja junačkog života i smrti Hifzi-bega Đumišića izražene su u skladu sa postulatima oblikovanja balade16: osmerac, dramska napetost, žustrina, dinamična smjena dijaloga, tragično osjećanje svijeta, zastupanje stavova, sukob sa društvom.

Formiranje kriterija po kojima se balada može svrstati u širi sistem južnoslavenskog narodnog naslijeđa djelo je Đenane Buturović koja posebno insistira na naglašavanju potrebe umjetničkog iskazivanja istorijskog saznanja te uopćavanja „narodnih predstava povijesti kroz lična osjećanja i sudbine svojih junaka“" (Buturović 1998: 631). Fenomen istorijske balade uporište nalazi u okvirima stradanja junaka i motiva izdaje. Posebno mjesto u takvoj konstelaciji zauzima junak muslimanske epske pjesme i balade. Junak kao takav ovaploćuje težnje naroda u liku heroja koji se zalaže za oslobođenje od ugnjetavača. Iako zadržava elemente istorijskog, junak je podvrgnut epsko-baladnoj transformaciji. Pored narodne svijesti, glavnog aduta u usmeno-folklorističkom oblikovanju dodatni prilog čine transformacije nastale u susretu sa „novim epohama narodne istorije i usljed preokreta u narodnoj svijesti“ (Kilibarda 2012: 158). U baladi koja računa sa istorijom, pogotovo ovoj poznijeg tipa sa elementima epskog, jasno se naziru procesi koji imaju karakter pomijeranja od „fantastike ka konkretnom istorizmu i jačanju realno životnih principa“ (Kilibarda 2012: 159). Taj postupak, kao što je to već naglašeno u uvodnom dijelu rada - je uzajaman. u istorijskim baladama kako smatra Boris N. Putilov u studiji o slavenskoj istorijskoj baladi, pažnja pjesme nije koncentrisana na opjevavanje sukoba ili epskih borbi niti istorijskih podviga, pred ovom pjesničkom usmenom vrstom nalazi se cilj predočavanja dramatske lične sudbine uslovljene društvenim životnim prilikama, što čini sadr-

14 Valja napomenuti da su zapisane pjesme nepotpune, bez imena pjevača te se po formi uklapaju u obrazac napjeva. u ovom radu se referiram na knjigu koja je objavljena 1983. godine.

15 Usp. Kapetanović Ljubušak Mehmed-beg. Istočno blago. T. 2. izd. Sarajevo: Svjetlost, 1987. Pjesma je zapisana prema pjevanju Džemila Kapetanovića.

16 Izvođenje balade o pogibiji Hifzi-bega Đumišića odvijalo se pjevanjem „u osnovi poravnim napjevom, najčešće uz pratnju saza (žičanog instrumenta, obično sa osam žica), ali također i bez pratnje“ (Maglajlić 1995: 35). Kada je u pitanju prezentacija ove pjesme kroz formu prenošenja i/ili pjevanja pa i performansa treba spomenuti da su ovu baladu izvodile i žene, bez obzira na njenu popularnost u mjestima muških druženja, prilikom praznikovanja i porodičnih skupova. 
žaj narodne balade. Istorijska balada nastaje na osnovu političke istorije koja se ogleda u tragediji junaka (usp.: Путилов 1965).

U odnosu na istorijske prijepore utemeljene u političko-ideološkim tendencijama naroda i sukobljenih, različitih strana, naglasak balade je na „brzoj junakovoj smrti i onome što ju je prouzrokovalo, a to je urota protiv junaka“ (Buturović 2010: 107). S druge stane junačka epika, koliko hrišćanskog toliko i muslimanskog tipa koje postoje ovisne i naslonjene jedna uz drugu ${ }^{17}$ obilježena je optimizmom ,a njeni junaci su gotovo redovito pobjednici“ (Lord 1998: 539). Istorijska ličnost i junak usmene pjesme Hifzi-beg Đumišić susreću se u tački i polju tragičnog stradanja, stoga se stavlja i naglasak na baladni karakter tog stradanja. Sve pjesme o Đumišiću i epskog i lirskog karaktera ne prate istorijski kontekst doslovno (fakciju iščitavamo iz niza različitih istorijskih zapisa) već se impulsivno preuzimaju okolnosti i ugrađuju i postoje filtrirani folklornim pojmovima i shvatanjima. Način na koji se odvija prelaz određen je herojsko-epskom stilizacijom (termin kojeg izvodi Gerhard Gesseman prateći djelo Matije Murka) kojim se osvjetljava proces ,podešavanja i prestilizovanja surovog događajnog gradiva prema određenom socijalnoumetničkom uzoru: njime se pojedinačni doživljaj uzdiže do socijalno-reprezentativnog oblika i obavezane vrednosti. To podešavanje u stvari je umetnički izraz socijalno-etičkog dejstva jedne kolektivne uzor-predstave“" (Schmaus 1998: 148). Ovaj rad, imajući u vidu specifikum istorijske balade kakve su varijante o Hifzi-begu Đumišiću dat će odgovore šta se desilo za vrijeme uslovno rečeno preoblikovanja istorije u usmenu poeziju, odnosno kako se i na koji način odvio susret stvarnosti ili zbilje sa folkolornom tradicijom.

\section{Uloga folklornih funkcija u sintetiziranju balade o Đumišiću}

Pitanje čemu korištenje folklornih funkcija pri interpretaciji muslimanskih istorijskih balada o Hifzi-begu Đumišiću utemeljeno je u pretpostavci koja uključuje praćenje i analizu mitskog, odnosno folklornog iz tradiconalnog karakterističnog i determinirajućeg za pojedini narod. Albert B. Lord navodeći da su „muslimanske narodne epske pjesme najdragocjenije na Balkanu“ akcentira da su jedino one ,sačuvale i razvile neke mitske uzore bolje od hrišćanske tradicije, koja je uperila sve svoje poglede više hajdučkim i kleftskim

17 Naravno da bi se u tom smjeru mogle razvijati i studije u kojima bi se poredbeno istraživali odnosi hrišćanske i muslimanske epike i uopšte usmenog pjesništva, način slikanja i tumačenja određenih istorijskih događaja. Tu posebno naglašavam razliku koja je ključna u poredbi a proizlazi iz zaključka Nade Milošević Đorđević koja u studiji o narodnoj književnosti navodi da se shvatanje epike može podijeliti na dva dijela prije i poslije Kosovske bitke s obzirom da je za srpski narod to bio najvažniji ,događaj njihove istorije, prelaz iz epohe postojanja slobodnih i samostalnih srpskih država u epohu robovanja pod Turcima“" (Usp. Milošević Đorđević. Narodna književnost. Sadržaj dostupan na web stranici Projekta Rastko v. literaturu). S druge strane, treba voditi računa o već pomenutom kontekstu političko-društvenih i kulturoloških tendencija Bosne za dekolonizacijom. 
pjesmama, a odatle i historiji“ (Lord 1998: 540). Navedeno treba uzeti s rezervom posebno radi bogatstva pjesama koje dolaze iz drugačijih tradicijskih krugova, specifičnosti različitih pjesama ponaosob, ali i iskoristiti kao povod teorijsko-kritičkim promišljanjima koja bi za cilj imala otkriće onog što znači način pjesničkog (pjevačevog) oblikovanja u dimenziji motivacije. Događaji o kojim pjevač priča da upotrijebimo Lordov izraz nametnut je „pjevačevoj pažnji svojom konkretnom sadržajnošću“ (Schmaus 1998: 149) te potrebi da se pjevač nametne i ,ili da ugodi publici ili da ne očekuje nikakvu nagradu“ (Lord 1998b: 345). U potrebi da se pjesme humanizuju, štaviše približe slušaocu koji se može identificirati sa svojim junakom, pa bar on bio i tragičan, pjevač mora da ponudi i bipolarno naslika folklorne elemente pogodne za identifikaciju i dosezanje emocije i angažmana (najčešće nepismenih) slušalaca u korist junaka. Navedene mehanizme prepoznajemo u didaktičkom aspektu recepcije bajke na nivou uzrasta djece. U nekom uslovno rečeno simplificiranom kontekstu nepismeni slušaoci mogu slijediti bipolarnu podjelu svijeta: pozitivne i negativne junake i u koncu proizvodnju univerzalnog otklona svijeta dobra i zla. Taj pristup biće značajan kako bi se sačinila rekonstrukcija koja je nužna pri shvatanju prijemčivosti samih pjesama, njihovom variranju i opstanku u tradiciji. Kad su u pitanju baladne (a i epske) varijante o pogibiji Hifzi-bega Đumišića koje su bitnim dijelom muslimanske kulture i tradicije, a u odnosu na Lordovu tvrdnju o očuvanju mitskog za neophodnim se ispostavlja da se pronikne u suštinu i bazu krajnje identifikacije običnog slušaoca sa svojim junakom, njegovim intimnim dramama, odnosima sa drugim junacima i na kraju sa samim društvenim okolnostima. Upravo u tome leži snaga istorijske balaade. Boris Putilov insistira da se prelom u sudbini pojedinca (privatne ličnosti) stapa sa tekstovima ljudskih osjećaja i epskih slika ljudskih sudbina koje su ,ponesene tokom istorije [a] (...) ovdje se kombiniraju tragično i herojsko. Jedna od najbitnijih karakteristika balade bila je ta da se u njima kako se čini urušio život ljudi iz doba jarma bezbroj pojedinačnih epizoda i privatnih slučajeva; međutim kako je to uobičajno za narodnu poeziju, jedinstvo ovog skupa je izuzetno snažno“ (Путилов 1965: 97). Stoga Hifzi-beg Đumišić postaje persona za identifikaciju slušalaca, a političke i društvene okolnosti u kojima se zbiva njegova tragedija pitanje opstanka zajednice i istorijske zbilje Bosanskog ili Seljačkog ustanka.

U nastavku rada neophodno je pratiti transformaciju događaja ili transmitovanje ličnosti Hifzi-bega Đumišića u baladni lik (izdajom tragično nastradalog junaka), mjesta istorijskog razvoja događaja uzroka i povoda usporediti sa motivskim jedninicama i mjestima i na kraju procijeniti na koji način povijesni događaj može rasvijetliti tamna mjesta balade te u obrnutom smislu kako narodna pjesma može doprinijeti recipiranju istorijske istine, odnosno u kojem su odnosu istorijske i pjesničke istine. Na kraju, ovi će zaključci rasvijetliti odnos istorijske i zbilje (baladne) pjesme te utvrditi njihove sličnosti i razlike u dinamičnom suodnosu egzistiranja ovih različitih diskursa. 
Zadatak stavljen pred Hifzi-bega, a zabilježen u istoriji određen je nejasnim okolnostima da je brašna bilo dovoljno za oko pet-šest dana kao i činjenicom da se brašno moglo otkupiti od muslimanskih begova. Zeki-pašina naredba je povod daljnjim istorijskim dešavanjima. Uzrok se krije u mutnim okolnostima pod kojim je paša donio takvu odluku a koja se tiče lošeg ili neopravdanog strategijskog poteza i zavisti nad junačkim sposobnostima svog podređenog. Usmena reprezentacija Đumišićeve pogibije pogoduje dekonstrukciji i izučavanju folklornih predstava smještenih u tradiciji. Za razliku od povoda i istorijskog uzroka, prema narodnim shvatanjima u pjesničku zbilju ulaze narodu bliske predstave što je komplementarno sa tezom Lade Buturović koja u knjizi Treptaj žanra u poetici usmene književnosti (2010) navodi postojanje dinamične strane u živoj tradiciji kojom se procjenjuju važni događaaji koji će se prenositi na buduće generacije. Predstave je neophodno morfološki razgraditi i analizirati u paralelnom izučavanju istorijske i pjesničke zbilje. Inicijalni stihovi balade utemljeni su u motivu izdaje koji je „razvijen postupno" (Maglajlić 1995: 36) i u skladu sa poetskim načelima balade, pri čemu se u ekspoziciji objašnjava spremnost likova na izdaju junaka. Balada počinje od potraživanja srpskog knjaza od Zeki-paše da izda Đumišića. Detalj od posebne vrijednosti je knjiga-pismo kao dvostruki simbol: zatvorenosti sigurnosti i tajne koja funkcionira kao žarišna tačka koncentracije na tragični događaj. U jednoj varijanti balade Salih Zeki-paša dobija dva puta knjigu dok se u drugoj pojačava razlog slanja poruke kroz „tajne kanale državničkih poslova: hvatanje Đumišića zajedno sa svim njegovim odličjima, onim što ga čini junakom i vojnikom — borcem“" (Buturović 2010: 108): njegovim mačem i konjem — najjačim oružjem u borbi.

Knjigu piše srpski knjaže, a na ruke Salih-paši, Salih-paši u Bjelinu, pa u knjizi 'vako kaže: „Salih-paša, diko naša, daj ti nama Hivzi-bega, Hivzi-bega Đumišića, i uz njega britku sablju i njegova b’ jelog ata, ja za srebro, ja za zlato, ja za koje drugo blago!"

(Maglajlić 1995: 240)

Usmena kreiranja lika Salih-paše i uvođenja srpskog knjaza ${ }^{18}$ umnogome zavise od oprirođenja lika protivnika koji ima funkciju da naruši sklad i iza-

18 Baladom je zahvaćen širi kontekst društvene i istorijske zbilje. Narodni pjevači zapamćuju Obrenovića srpskog kneza, koji traži izdaju bega Đumišića, što je predimenzioniranje junačkih sposobnosti junaka (pjesnički fenomen). 
zove nesretan događaj. Stoga su pitanje tradicionalnog poretka u svijetu: dobra i zla. Dijalog knjaza i paše ${ }^{19}$ teče na način da ,protivniku se daju obavještenja o njegovoj žrtvi“ (Prop 1982: 36). Pašino kolebanje popušta u trenucima kad prešutno pristaje na dogovor izdavajući naredbu Đumišiću da krene po brašno. Nesumnjivo ovaj motiv izdaje sadrži propovski „obrnuti vid zabrane“, tj. naređenja na koji se ndovezuje nesreća koja je prijetnja junakovoj sreći i sposobnostima: ,jer za Himzu i car znade, / i carevi svi veziri/da je Himzo muška glava“ ${ }^{20}$. S druge strane, detektirani element je mjesto Maglajlićeve tvrdnje o nužnosti izdaje za oblikovanje balade. Preciznije, nužnosti zavisti. Navedeni stihovi balade označavaju i strah Salih-paše. Motiv naređenja sadrži isključujuće pojedinosti od prešutne saglasnosti na izdaju, preko načina odašiljanja naredbe uz pjesmu i muziku. Riječ je o fenomenu neposrednog odašiljanja junaka. Napominjem da je trenutak odlaska u Raču radi brašna u nekim varijantama pjesme izostavljen što je u suprotnosti sa istorijom i utiče oslabljenjem na uvjerljivost plemenitog pohoda. Suprotstavljanje Hifzi-bega nadređenom sadrži nekoliko varijanti s akcentom na sljedećim detaljima: Salih-paša izgubio pamet/poludio, Salih-pašu naziva murtatinom (izdajnikom, dušamaninom) ali se i cinično podsmjehuje njegovoj naredbi. Motiv smijeha u usmenoj ili narodnoj književnosti je u direktnoj vezi sa samim životom i smrti. Polazeći od Čajkanovićeve tvrdnje da se epski junaci nerado smiju, preko određenja smijeha kao sarkastične reakcije junaka na okolnosti ili manifestaciju moći, pa okultnih i/ili religijskih vrijednosti, magijski smijeh Hifzi-bega Đumišića može se odrediti kao usiljen i deplasiran smijeh. Kazano riječima Veselina Čajkanovića za „usiljen smej mora postojati kakav dobar razlog, recimo: preterana ljubaznost, kapris, strah, ili kakva bilo potreba da se pravo raspoloženje sakrije“(Čajkanović 1973: 55). Istovremeno Đumišić skriva raspoloženje izazvano naslućenom izdajom i vlastitom spremnosti da krene u smrt. ${ }^{21}$ Stoga ne iznenađuje stav junaka kojim se potvrđuje važnost smijeha jer reakcija „smej (...) najpouzdaniji je utuk za smrt" (Čajkanović 1973: 64). Pjesma kazuje:

\author{
„Salih-paša, muko naša, \\ zar si bolan poludio, \\ ili pamet izgubio: \\ gdje će ići dva buljuka, \\ dva buljuka u Srbiju!"
}

(Maglajlić 1995: 242)

19 Baladna struktura poznaje i afirmira formu dijaloga koji u slučaju balade o Hifzibegu postaje forma za funkciju odavanja informacija protivniku.

20 Sintagma muška glava se odnosi na junaštvo, pojačano srodnicima junacima muške loze porodice. Odnosi se istovremeno na zamjenu muških članova porodice koji u slučaju tragedije mogu (i junaštvom) zamjeniti Hifzi-bega. Stoga je ovo najava tragičnog događaja ali i opravdanje onakvog darivanja koje čini junak na samrti.

21 Odnos prema smrti i upotreba smijeha proizlaze iz shvatanja da smrt ne predstavlja kraj, već nastavak života kojim se živjelo na zemlji. 
„, Salih-pašo, murtatine, murtatine, dušmanine!

il'si bolan poludio,

il'si pamet izgubio

il' je nisi ni imao?"

Knjiga dođe Himzi-begu,

knjigu uči, a smije se;

pa pokupi svu redifu i miliju,

pa on ide sad na Raču,

sad na Raču rastaina.

(Kuba 1984: 98)

Hifzi-beg pristaje na izvršavanje naredbe isključivo radi svojeg junaštva. U katalogu Propovih funkcija nalazimo odgovarajuću, neprijateljevo korištenje „otežavajućom situacijom žrtve i slanja junaka u potragu zbog oskudice“ (Prop 1982: 38-42). Iako svjestan izdajničke naredbe, Đumišić se (kao i svaki junak) ne ogluši na naredbu. U odnosu na baladnog junaka čitamo mat poziciju: „vlast ciljala na Hifzi-begovu čast i na to da nema vremena da mnogo razmišlja. Doveden je u situaciju da reagira brzo" (Buturović 2010: 109). U istorijskim zapisima nema tragova begovom pružanju otpora što za baladu znači potenciranje i predimenzioniranje junačke časti. Istovremeno se ističe Hifzi-begova predodređenost za stradanje zarad plemenitih ciljeva. Na baladni element opravdanja postupka junaka nadovezuje se motiv svjesnom odlasku u susret opasnosti. U baladnim varijatama događaja on je transformisan na način da baba i agent (u epskoj) te srpsko momče i baba ili sama baba (u baladi) upozoravaju Đumišića na opasnost povratka istim putem. U epskoj poeziji našeg konteksta dar govora jeste proročki dar. Baladni lik babe u funkciji je darivaoca ili snabdjevača: ,darivalac pozdravlja i ispituje junaka“ (Prop 1982: 47). Baba, također, može biti i zlokobni simbol najave smrtne opasnosti ili mamac junaku da odustane od podviga. Babom se naglašava predispozicija junaka za stradanje i lišavanje njegovih junačkih obilježja.

Kad je bio blizu Rače,

Susrete ga stara baba,

I sa babom mlado Srpče,

Mlado Srpče gologlavo,

Pa je njemu govorila,

Hifzi-begu kazivala:

„Hifzi-beže carski sine,

Znaš li beže, kuda ideš?

Ti ćeš ludo poginuti,

Rusu glavu izgubiti!“

(Maglajlić 1995: 242)

Argument babinoj određenosti funkcijom davanja informacija junaku potvrđujem i dimenzijom uvođenja lika u folklorističke teme: reakcija junaka 
na postupke darivaoca koja može biti i „negativna“ (Prop 1982: 50). Hifzi-beg u skladu junačkom etikom ne obraća pažnju na upozorenja babe, u nekim varijantama je tjera, daruje dukatom te odgovara na njena upozorenja:

„Hajd' otolen stara babo,
evo tebi zlatan dukat,
pa ti hajde svojoj kući,
svojoj kući, pa ti muči!
Volim muški poginuti,
neg se ženski povratiti!"“

(Maglajlić 1995: 243)

Navedeni stihovi pokazuju Đumišićev odnos prema junačkom sistemu vrednota. Univerzalni sistem pripisuje odluke hrabrosti i herojstva muškarcima kao i spremnost da se ide ravno u smrt, čime nedvosmisleno „odbija svaku mogućnost povratka i odustajanja od pohoda“ (Maglajlić 1995: 39). Hifzi-beg svjesno odbija svaku nedoličnu primisao ili postupak (kukavički) koji bi obeščastio junaka i njegov podvig te ga bacio u zapeća tradicije, što će se dokazati kao presudno u trenucima Hifzi-begovog opraštanja. Veza među herojstvom i porodicom ukazuje na težnju očuvanja ugleda porodice kojoj junak pripada. Čak i postupak opraštanja od porodice (halal) označava rješenost, kako veli Maglajlić da beg ide u susret smrtnoj opasnosti ili kao predosjećaj nadolazeće smrti. U varijantama balade motiv borbe i smrtnog ranjavanja sadržan je i razvijen na postepen način. Đumišić se susreće sa dvije i strada u trećoj busiji sa presudnim osmim ili sedmim topom. U pamćenju istorije tragičnog stradanja beg u noći susreće zalutale vojnike koji ga upozoravaju na povlačenje neprijateljske vojske, savladavši prvo „dvije pripravljene zasjede“ (Muderizović 1927: 8-9) i u konačnici stradao u trećoj pomno pripravljenoj busiji. Sumnju $\mathrm{u}$ istoriju izaziva ponavljanje broja tri22 (zasjede) karakterističnog usmenog obrasca kojim se akcentira određeni događaj od važnosti za folkloristiku. U razvijenijim varijantama u boju na Rači Đumišić se sreće sa Đokom Vlajkovićem. S njim Hifzi-beg ratuje te u bogatijim varijantama i dijalogizira.

\section{Kad je bila treća klasa, treća klasa Vlajkovića Đoka, izlazio Vlajkovića Đoka,}

22 Kad je u pitanju simbolika brojeva u usmenoj ili narodnoj književnosti, Tomo Maretić u svojoj knjizi Naša narodna epika. Kniga IV (1909) posebnu pažnju posvećuje takozvanim stajaćim i nestajaćim brojevima, odnosno onim koji su u čestoj ili rijetkoj upotrebi. Slijedeći Vuka, Maretić „,među stajaće crte naše narodne epike [smješta pripadajuće] brojeve“ (Maretić 1909: 91). Pojava brojeva u narodnoj pjesmi veže se za načine opisivanja. Tako se prepoznaje značaj i repetitivnost običnost malih, običnih brojeva, među kojima se pominju i brojevi 3 i 7 kao najčešće upotrebljivani, dok „osobito je 8 vrlo rijedak broj“ (Maretić 1909: 91). Razlog upotrebi brojeva 3 i 7 autor knjige pronalazi u prastarim pripovjednim vremenima utemeljenim u pričama. Kako za broj 3, tako i za broj 7 Maretić navodi da upotreba navedenih brojeva ne samo da je starija od hrišćanstva te svojstvena Homeru ili da je mehanizam usmenog pripovijedanja, nego da je „veoma običan u pričanju i pjevanju mnogijeh naroda“( (Maretić 1909: 92). 


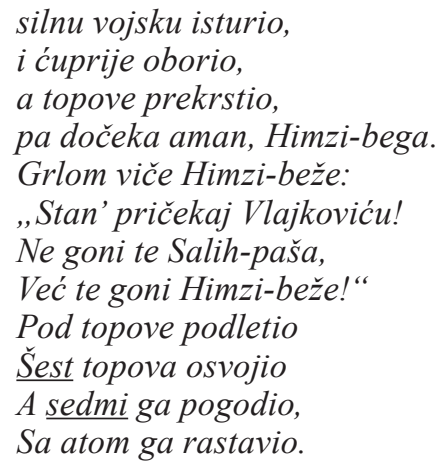

Đoka Vlajković zauzima mitsko mjesto u sprskoj istoriji, kulturi i tradiciji. Obnašao je dužnost pješadijskog pukovnika i majora i s nastupom Hercegovačke bune pomaže ustanak Srba u Bosni. ${ }^{23}$ Između 3. jula i 14. septembra, Vlajković (sa odredom italijanskih dobrovoljaca Garibaldinaca) se neuspješno sukobio sa bijeljinskim muslimanima. Važnost ovih datuma potvrđuje istorijska blizina datuma pogibije bega Đumišića. Svakako uz čuvenost Vlajkovićeve trupe i istorijska podudarnost, važni su pokretači bržeg zapamćivanja i ulaska u usmenu poeziju i pripisivanje boja sa Đumišićem. ${ }^{24}$ Vlajkovićevo junaštvo i lik osvjedočeni su pjesmama o pogibiji Hifzi-bega, koja ga pamti (u nekim varijantama) kao hrabrog i sposobnog ratnika. ${ }^{25}$

Bogatstvo varijacije motiva opraštanja umirućeg junaka sa muškim članovima porodice, bega sa zemaljskim životom i pre/davanje u naslijeđe simbola junaštva i muškosti je posljednji u nizu dinamičkih motiva razvoja radnje balade. Iako se tragično razdvaja od junačkih obilježja, on i „,dalje stremi da bude model“" (Buturović 2010: 98) junaka, svjestan ispunjenja herojskog cilja. Osvajanjem kontrole nad situacijom junak ulazi u tradiciju svjestan svrhe svog života i smrti. Ratnu opremu i lične predmete (sablja, at, ahat, prsten, ogledalo i hamajlija) umirući Hifzi-beg salje trojici svoje braće: Muharemu, Fehim-agi i Mustaj-begu u nekim varijantama i sinu, te dajdži Derviš-begu Teskeredžiću s kojim je dijelio odanost vojnom sistemu od 1964. godine preko sluge Ibrahima šalje molbu da mu „uči zlatan enam“ (Maglajlić 1995: 244). ${ }^{26}$ U nekim

23 u svim srpskim krajevima, naročito onim preko Save, za dobrovoljce koji su odlazili da se bore protiv Turaka govorilo se "idu Đoki Vlajkoviću".

24 Veše detalja o značaju ličnosti Đoka Vlajkovića provjeriti u: Sofronijević Mira. Darivali su svome otečestvu: Đoka Vlajković — ratnik-zadužbinar. Beograd: Biblioteka grada Beograda \& International Publishing, 1995.

25 Na primjer, u tekstu pjesme Beg Himzi-beg koju je zapisao srednjoškolac Mato Vincetić (Bijeljina 1890) od inicijalnog stiha pominje Vlajkovića u funkciji antipoda Himzi-begu. Maglajlić analizirajući motiv smrtnog ranjavanja junaka primjećuje upravo tu suprotstavljenost.

26 Ovdje je ponabolje enam shvatiti u prenesenom značenju. u Kur'anu i šesta sura El-Enam, koja je vjerovatno bila napisana na papiru i stavljena na junaka kao neki vid hamajlije koja će ga štititi od zla. Konsultujući Školski rječnik bosanskog jezika Dževada Jahića ustanovljeno je značenje arabizma enam-hamajlija — vrsta hamajlije, zapisa (Jahić 1999: 208). 
varijantama sablju šalje samom sultanu, a pjesma pamti povijesne činjenice o boravku brata Fehim-age u Stambolu za vrijeme smrti Hifzi-bega.

\begin{tabular}{l} 
Ranjen beže progovara, \\
pa doziva svoga Hamzu: \\
uriš“ \\
\hline da se asker ne pometa. \\
Opet beže progovara: \\
"Husenine dragi brate, \\
ufati mi b'jelog ata, \\
pa ga vodi Banjoj Luci \\
nek mi gleda belog ata, \\
već ne vidi Himzi-bega; \\
otpaši mi britku sablju, \\
britku sablju demišćiju, \\
pa je ča šalji u Stambul \\
mome bratu Fehim-agi \\
nek mi gleda britku sablju, \\
već ne gleda Himzi-bega."
\end{tabular}

(Kuba 1984: 99)

Balada bilježi i motiv Hifzi-begovog darivanja majke, rastanak sa ženom i poruku Salih-paši. Poruka izdajniku dolazi u vidu pjesme pjevača Hamze ili Ibrahima koji svjedoči o begovom ratništvu. Važan lik u funkciji pomoćnika Hamza ili Ibrahim ima zadatak da izvrši oporuku umirućeg junaka. Evidentna je lirska nedoslijednost $u$ transformaciji istorijskih činjenica u baladne. Jedan takav primjer je zapamćivanje Hifzi-begove braće. Pjesme u svim inačicama s motivom darivanja pamte tri Đumišićeva brata: Muharema, Fehim-agu i Mustaj-bega. Istorija pokazuje drugačije. Đumišić je pored pomenute imao i četvrtog, najmlađeg brata Ali-bega. ${ }^{27}$ Broj četiri nije poetičan, ni simboličan i nema ulogu u usmenoknjiževnoj tradiciji. Nesrazmjer između stvarnosti i pjesničkog preoblikovanja događaja, kad je u pitanju motiv opraštanja umirućeg junaka, pokazuje na najbolji način ulogu folklorističkog usmenog naslijeđa kao temeljnog principa.

\section{Od istorije do poezije}

Nakon identificiranja sličnosti i razlika na paradigmatskim primjerima balada o pogibiji Hifzi-bega Đumišića i istorijske zbilje, utvrđeni su načini preoblikovanja istorijskih činjenica i njihovog ulaska u tradiciju i procese zapamćivanja. Interpretacija istorijskih podataka i stihova potvrdila je načine preoblikovanja, transmisiju istorijskog u pjesničko. Analizom je utvrđen i sa-

27 Usp. Kamberović Husnija. Begovski zemljišni posjedi u Bosni i Hercegovini od 1878. do 1918. Sarajevo: Naučnoistraživalački institut Ibn Sina, 2005. 
držaj „kao i način pamćenja“ (Buturović 2010: 93).28 Akcenat u istorijskim događanjima je na motivu uzroka i povoda, a u pjesničkom na prepoznatim motivima balade. U dinamici razvoja dramatičnog događaja (istorijskog i baladnog) od ključne pomoći bile su funkcije bajke. Razlog odabiru Propovih funkcija leži u dinamici razvoja događanja (balada i nizanje motiva) te u njihovom sintetiziranju u baladu, te prepoznatljivosti i opštoj prihvaćenosti ovih motiva u tradicijama i kulturama svih naroda. S druge strane, ova ideja je potekla iz sugestije Alberta B. Lorda koja je na tragu specifičnosti muslimanske istorijske balade koja je specifična upravo i po upotrebi što vodi do zaključka da Hifzi-beg Đumišić nije tipski epski junak, nego prije međašni lik koji sobom ovaploćuje istorijske asocijacije (s rezervom da jeste u korelaciji sa stvarnim istorijskim ličnostima „one se estetski i ne percipiraju kao likovi koji mogu biti prototipi hronici“ (Путилов 1965: 27)), mitsku tragiku, izraženu bajoslovnu bipolarnu osnovu i muslimansku tradiciju. Dovođenje u vezu funkcija bajke i balade opravdano je i na nivou rekonstrukcije i recepcije, te konstituisanja baladnog narativnog sklopa. Pomna interpretacija je pokazala u kakvoj su sprezi istorijski, epski i baladni narativ, odnosno istorija provučena kroz tradiciju i domaštana pjesnička zbilja.

Prepoznavanje elemenata funkcije bajoslovnog narativa i upliva epskog u sintezi baladne pjesme o Đumišićevoj pogibiji rezultira građenjem folkloristički zapamćenijih istina. Pitanje od posebne važnosti jeste karakter uzajamnog odnosa istorijske i baladne zbilje. Na koji način istorijski događaji mogu rasvijetliti tzv. tamna mjesta balade? S obzirom na to da ova dva narativa nude različite ,istine“ 29 i probleme koje proizvode gledišta i tumačenja događaja, onda je ispravno zaključiti da se u oba narativa iskazuje težnja za dominacijom i pravom na istinu. Istorijska i pjesnička zbilja računaju na potencijal gradnje kulturološke moći kojom se ostvaruju prava na političke pozicije. Identična je situacija i s pitanjem kako narodna pjesma doprinosi recepciji istine. Uzimajući u obzir da sve strane polažu pravo na istinu i moć, supostojanje istina (istorijskih i pjesničkih) doprinosi pluralizmu i premošćava granice dva suprotstavljena diskursa. Na taj način istorijski i književnoumjetnički diskurs fukncioniraju u javnom prostoru. Istorija i književnost imaju ulogu u izgradnji svakog nacionalnog narativa čemu svjedoče i pristrasni načini intepretacije istorijskog i baladnog narativa. Hegemonijski narativi koji su najčešći zagovarači „naučnih principa“ koji podupiru i idu u prilog bildanju nacionalnih priča i dominirajućih tradicija negativno procjenjuju druge tobožnje neprijateljske tradicije. Vodeći posebno računa o unutrašnjim, internalizovanim balkanizamskim predodžbama jednog balkanskog naroda o drugima i obrnuto, razjaš-

28 Dakako da se načinima zapamćivanja moglo pristupiti i s aspekta kulturološkog pamćenja i procesa sjećanja, ali ovakav tip analize (cjelokupnog događaja, ne segmenata, kao dinamično-dramatičnog čina) pogoduje upravo analizi kakvu sam primjenila u tekstu.

29 Ciljam na razlike istorijske i fikcionalne istine. Književnost nije lažna istorija. Književnost je naracija koja „odaje privid istinitog“"koji je sličan sa jeste istinom. Najtačniji zaključaj o funkciji „književnosti da učini fikciju istinom“ (Hamburger 1982: 107). 
njavanje konteksta pojave baladnog kruga o Hifzi-begu Đumišiću ide u prilog raščlanjivanjima i dekonstrukciji istih na nekoliko nivoa: dokazati legitimno supostojanje paralelnih i nerijetko oprečnih istorijskih narativa o istim događajima koje treba kao takve (inkluzivno) sagledati, posebno činjenice koje se tiču ustanka podjarmljenog (srpskog) naroda Bosne protiv turskog kolonizatora, zatim i tendencija muslimanskog naroda u Bosni na osamostaljenje od svih osvajača; te u kulturološkom kontekstu neophodno je priznati i uključiti muslimansku tradiciju koja s margine treba biti kontekstualizirana i interpretirana u najširem slavenskom kontekstu kao dio tradicionalnog pluralnog bogatstva i u spezi s potonjim posebno istaknuti činjenicu da baladna tradicija muslimanskog konteksta, a u vezi s Hifzi-begom Đumišićem pamti i odgovornost izdaje koju nosi njegov vlastiti narod. Suprotne analize politički obojene ne predstavljaju stvarni doprinos nauci, stoga je uvijek potrebno apelirati na neutralnost i objektivnost istraživača/ice koji/a u osnovi svojih naučnih istraživanja treba sačiniti što potpuniju sliku ogledanja istorije u književnosti, njihova suodnosa i uloge koju imaju u podupiranju centara moći.

\section{LITERATURA}

Asman Alaida. „O metaforici sjećanja“. Reč. Časopis za književnost i kulturu, i društvena pitanja 9 (1999): 121-135.

Bejtić Alija. „Prilozi proučavanju naših narodnih pjesama“. Bilten instituta za proučavanje folklora 2 (1953): 387-407.

Bejtić Alija. „Prilozi proučavanju naših narodnih pjesama“. Bilten instituta za proučavanje folklora br 3 (1953): 105-124.

Bošnjačka književnost u književnoj kritici. Knjiga II - Usmena književnost. Sarajevo: Alef, 1998

Buturović Lada. Treptaj žanra u poetici usmene književnosti. Sarajevo: Svjetlost, 1953.

Buturović Đenana. Bošnjačka historijska balada - dio južnoslavenskog kruga: Bošnjačka književnost u književnoj kritici. Knjiga II - Usmena književnost. Sarajevo: Alef, 1998.

Ekmečić Milorad. Ustanak u Bosni 1875-1878. Sarajevo: Veselin Masleša, 1973.

Hadžijahić Muhamed. „Hifzi-beg Đumišić“. Novi Behar (15 januara) VII/11-14 (1934): 174-175.

Hamburger Kate. Istina i estetska istina. Sarajevo: Svjetlost, 1934.

Imamović Enver i dr.. Bosna i Hercegovina od najstarijih vremena do kraja Drugog svjetskog rata. Sarajevo: Bosanski kulturni centar, 1998.

Imamović Mustafa. Historija Bošnjaka. Sarajevo: Bošnjačka zajednica kulture Preporod, 1998.

Jahić Dževad. Školski rječnik bosanskog jezika. Sarajevo: Ljiljan,1999.

Kamberović Husnija. Begovski zemljišni posjedi u Bosni i Hercegovini od 1878. do 1918. godine. Sarajevo: Naučnoistraživalački institut „Ibn Sina“, 2005.

Kapetanović Ljubušak Mehmed-beg. Istočno blago. T.2 izd. Sarajevo: Svjetlost, 1987.

Kilibarda Novak. Ogledi o crnogorskoj usmenoj književnosti. Podgorica: Intitut za jezik i književnost, 2012.

Krnjević Hatidža. Usmene balade Bosne i Hercegovine. Knjiga o baladama. Knjiga balada. Sarajevo: Svjetlost, 1973.

Kuba Ludvik. Pjesme i napjevi iz Bosne i Hercegovine. Sarajevo: Svjetlost, 1984.

Lord B. Albert. Uticaj turskih osvajanja na balkansku epsku tradiciju. Bošnjačka književnost u književnoj kritici. Knjiga II - Usmena književnost. Sarajevo: Alef, 1998.

Lord B. Albert. Pjevači: izvođenje i obuka. Bošnjaka književnost u književnoj kritici. Knjiga II - Usmena književnost. Sarajevo: Alef, 1998b. 
Maglajlić Munib. Usmeno pjesnišstvo od stvaralaca do sakupljača. Tuzla: Izdavačka djelatnost Univerzal, 1989.

Maglajlić Munib. Usmena lirska pjesma, balada i romansa. Sarajevo: Svjetlost, 1991.

Maglajlić Munib. Usmena balada Bošnjaka. Sarajevo: Preporod, 1995.

Maretić Tomo. Naša narodna epika. Kniga IV. Zagreb: Štampa dioničke tiskare, 1909.

Muderizović Riza. „O junačkoj smrti Hifzi-bega Đumišića“. Novi Behar 1 (1927): 8-9.

Prop Vladimir. Morfologija bajke. Beograd: Prosveta, 1982.

Rizvić Muhsin. Bosansko-muslimanska književnost u doba preporoda (1887-1918). Sarajevo: El-Kalem, 1990.

Spahić Midhat. Junaštvo Hifzi-bega Đumišića. <http://www.scribd.com/doc/71957378/Junastvo-Hifzi-bega-Djurmisica $>04.08 .2020$.

Tanović Bakir. Historija Bosne u okviru Osmanskog carstva. Sarajevo: Svjetlost, 2010.

Todorova Marija. Imaginarni Balkan. Beograd: Biblioteka XX vek, 2006.

Šmaus Alois. Studije o krajinskoj epici. Bošnjačka književnost u književnoj kritici. KnjigaUsmena književnost. Sarajevo: Alef, 1998.

Маглајлић Муниб. Од збиље до йјесме. Ог̃леди о усменом сииваралащйву. Бања Лука: Глас, 1983.

Милошевић Ђорђевић Нада. Народна књижевности. Пројекат Растко. $<$ https://www.rastko.rs/isk/isk_11.html\#_Toc412459755> 25.12.2020.

Путилов Борис. Славянская историческая баллада. Москва - Ленинград, Академия наук СССР, Иститут русской литературы, 1965. <https://www.booksite.ru/fulltext/ slavballad/text.pdf> 25.12.2020.

Софронијевић Мира. Даривали су своме ойечесӣву. Бока Влајковић-райникзадужбинар. Београд: Библиотека града Београда, 1995.

Чајкановић Веселин. Мит̄ и религ̄ија код Срба. Београд: Српска књижевна задруга, 1973. $<$ https://ivoandric.no/biblioteka/Istorija/Veselin\%20Cajkanovic\%20-\%20Mit\%20i\%20 religija\%20kod\%20Srba.pdf $>25.12 .2020$.

Чубриловић Васо. Босански устианак 1875-1878. Београд: Српска краљевска академија, 1930.

Maglajlić Munib. Od zbilje do pjesme. Ogledi o usmenom stvaralaštvu. Banja Luka: Glas, 1983.

Milošević Đorđević Nada. Narodna književnost. Projekat Rastko. $<$ https://www.rastko.rs/isk/ isk 11.html\# Toc412459755> 25.12.2020.

Putilov Boris. Slavyanskaya istoricheskaya ballada. Moskva — Leningrad, Akademiya nauk SSSR, Istitut russkoj literatury, 1965. <https://www.booksite.ru/fulltext/slavballad/text. pdf $>25.12 .2020$.

Sofronijević Mira. Darivali su svome otečestvu. Đoka Vlajković - ratnik-zadužbinar. Beograd: Biblioteka grada Beograda, 1995.

Čajkanović Veselin. Mit i religija kod Srba. Beograd: Srpska književna zadruga, 1973. <https:// ivoandric.no/biblioteka/Istorija/Veselin\%20Cajkanovic\%20-\%20Mit\%20i\%20religija\%20kod\%20Srba.pdf > 25.12.2020.

Čubrilović Vaso. Bosanski ustanak 1875-1878. Beograd: Srpska kraljevska akademija, 1930.

Merima Omeragić

\section{FROM HISTORICAL DEATH OF HIFSI-BEY ĐUMIŠIĆ TO THE BALLADESQUE REPRESENTATION OF REALITY}

\section{Summary}

This work analyses the historical and artistic literary methods employed in the transition from the historical person Hifzi-bey Đumišić to a literary character. The unravelling of the relationship between the historical reality and the oral literary reality or the path of transforma- 
tion / poetization is a matter of memorization of the hero and the motifs in the Tradition (oral model) through modification, discontinuity and folklorization. The motif of betrayal and perishing was decisive for the ballad, while heroic strength and the magnanimity of his deeds shaped the epic. Literarization treats the motif of perishing on two levels: identification and recognition of the folkloric representation in the historical narrative/memorization, and its introduction in the tradition and additional imagining (of the folkloric representation of people). The emphasis in history is on the theme of cause, while in songs it is on the themes of the ballad. The comparison of historical and poetic data in the oral literary memory validates the modes of reshaping and transmission of the historical into the oral poetic. Solid interpretation is necessary in order to show the mutual realtionship of historical, epic and balladesque narrative, or to understand the way in which history, tradition and even imagined reality intself are expressed. Clarification of all mentioned contexts, in addition to poetic literary and critical value, alsko has the power of the socila, which is reflected primarily in inclusion of Muslim cultural values in Slavic contexts. tions.

Key words: historical narrative, poetization, variations, folkloric function, reality rela- 